\title{
Forensic Accounting and Fraud Prevention in Nigerian Public Sector: A Conceptual Paper
}

\author{
Abdulrahman, $\mathrm{S}$. \\ Department of Accounting \\ Faculty of Social and Management Sciences \\ Bauchi State University, Gadau, Bauchi State, Nigeria \\ E-mail: abdulningiI7@gmail.com \\ Tel: +2347035597220, +2348054415878
}

\begin{abstract}
This study examines forensic accounting and fraud prevention in Nigerian public sector by using some selected studies from within and outside Nigeria. The objectives of the study are to determine how does forensic accounting prevents fraud in Nigeria Public Sector and to determine whether forensic accounting prevents fraud in Nigeria Public Sector. To achieve the stated objectives of the study, data were collected from secondary source or Content Analysis. Based on the analysis, the study found that a significant positive influence exists between forensic accounting techniques and fraud prevention. The paper is of the opinion that more steps should be taken to ensure fraud prevention with the application of forensic accounting techniques. Moreover, an effective and thorough legal framework should be developed and be provided for effective enforcement of what the law say by government agencies that were saddled with such responsibility on behalf of the government.
\end{abstract}

Keywords: Forensic Accounting, Fraud Prevention, Public Sector, Fraud Triangle Theory, Fraud Diamond Theory

\section{Introduction}

Fraud is part and parcel of a cancerous threat that negatively affects the Growth and Development of any nation which shouldn't be underestimated globally. It is part of the reasons why there is need for forensic accounting to play a major role toward preventing fraud in Nigerian public sector. Fraud can be seen as an act of doing unlawful thing which portrays the violation, concealment of trust. While forensic accounting is targeted toward detecting and preventing an individual or corporate body from doing an act of questionable character or integrity. Now, if forensic accounting is expected to be seen as an aspect of accounting that is suitable for legal review and offering the highest level of assurance, then why in spite of the fact that some law enforcement agencies such as an Independence Corrupt Practices and other related offences Commission (ICPC), Economic and Financial Crimes Commission (EFCC), and Code of Conduct Bureau (CCB) these agencies are working day and night in tracing hidden assets, funds and many more but still fraud is at alarming rate in Nigeria?

Observation from previous studies such as Effiong (2013) who observed that the rate at which fraud is been perpetrated in Nigerian public sector is seriously at alarming rate. Moreover, Kasum (2009) has also clearly shown that corruption has affected the lives of citizens of third world countries negatively, which is engraved in the systems; it is at alarming and seriously devastating. Therefore, Forensic accounting is necessary towards reducing frauds, fraudulent activities and corruption capable of destroying national image and economic growth. In Nigeria, fraudulent practices have become much endemic and systemic, particularly in the public sector. However, Nigeria's case is unique owing to the fact that both the magnitude and the frequency of occurrence of the menace are very high (Agbiboa, 2012; Gbegi \& Okoye, 2013; Modugu \& Anyaduba, 2013; Nekede \& Oko, 2013). Nigeria has remained among the developing countries of the world and it is certain that the nations with high incidence of fraud cannot forge ahead (Owojori \& Asaoulu, 2009). Nevertheless with the incoming present administration things have started taking shapes but at minimal level due to the outrageous epidemic of fraudulent acts been committed by the past administrations. For instance Foreign Reserve increased from $\$ 29.6 \mathrm{bn}$ to $\$ 47.5 \mathrm{bn}$ as at May, 2018.

Forensic accounting is understood to have evolved in response to certain emerging fraud related cases. For example ENRON and WorldCom scandals have drawn or shocked the world and exposed corporate deceit and greed embedded in human minds to the field of forensic accounting, more and more attention is now given to the field (Ozuomba, Ofor \& Okoye, 2016). Moreover, financial related fraud and increase in financial crime has led to the need of forensic accounting in order to aid investigation and prosecution of the syndicates of financial crimes just liked in the case of some prominent political parties exgovernors in Nigeria are presently facing trials on money laundering, embezzlement, misappropriation of funds, security fraud, breach of contract from different court of laws within the country and many more including some public civil servants that converted public treasury as personal assets to their pockets. 
The related reviewed literatures revealed that majority of these frauds in the public sector are perpetrated by management officials who under normal circumstances are supposed to be the custodians and supervisors of internal control system and internal auditors respectively (Adebisi \& Gbegi, 20I5).

It is on the bases of these high increases in cases of fraud and other questionable acts that called for the need of thorough research to be carried out on forensic accounting in Nigerian Public Sector by looking at the previous findings of other researchers to do comparative analysis on whether there is cordiality between forensic accounting and fraud prevention or the researchers were just merely wasting their time in establishing the relationship where there is none even signal of relationship.

This study is targeted toward achieving the following specific objectives: To determine whether forensic accounting techniques prevents fraud in Nigerian Public Sector and to find out how does forensic accounting techniques prevents fraud in Nigerian Public Sector. The study is expected to be of significance more especially to the following potential beneficiaries namely employees, management, policy makers, judiciaries and finally to the public at large. The study is restricted to the parties concerned.

The study is structured as follows: Section one deals with the introduction as aforementioned, section two deals with literature review, section three contained research methodology adopted, while, section four is about discussions and, finally, section five concludes and makes some recommendations.

\section{Literature Review}

\section{I Conceptualization of Forensic Accounting and Fraud Prevention}

It is a well-known fact that there is no any worldwide or universally acceptable definition of forensic accounting and fraud. Nevertheless, some scholars made an attempt to define it based on their little understanding. For instance, (Ozuomba, Ofor \& Okoye, 2016) looked at Forensic accounting as the utilization of accounting, auditing and investigative skill to assist in legal matters and applies specialized body of knowledge to the evidence of economic transaction and reporting suitable for court proceedings and accountability. Joshi (2003) defined forensic accounting as the application of specialized knowledge and specified skill to stumble up on the evidence of economic translations. Crumbley (2003) opined forensic accounting as an accounting analysis that can uncover possible fraud that is suitable for presentation in court.

Coenen (2005) stated that forensic accounting involved the application of accounting concepts and techniques to legal problem. Zysman (2004) defined forensic accounting as the integration of accounting, auditing, and investigative skills. To the researcher point of viewed, forensic accounting is the application of specialized accounting skills and scientific bases to investigate the rudimental level of perpetrators act of artificial accounting activities that deals with financial record of that particular organization be it public or private sector from within and outside the dormant of the organization for legal justification in a court of law.

While, from the concept of fraud, Watoseninyi (I996) viewed fraud as irregularity involving criminal deception to obtain an unjust or illegal advantage. Fraud is an intentional misrepresentation of financial information by one or more individuals among management, employees or third parties (Dandago, 1997). The research intends to define fraud as an act of criminal deception and intentional misrepresentation of financial information by one or more individuals among the top, lower or mixed cadre of employees, management or third parties with the sole aim of obtaining unjust or illegal advantage of one or more selfish interest in the organization.

Conceptual and Empirical Studies on Forensic Accounting from within and outside Nigeria were reviewed: Okoye and Gbegi (2013) examined forensic accounting as a tool for fraud detection and prevention in Kogi State, Nigeria. The findings revealed that the top management and senior staff are aware of forensic accounting while very few of the lower cadre has knowledge of forensic accounting. The study recommended that government and the private sector organizations in the light of present day fraud related activities in the public sector need to develop interest in forensic accounting and accountants for monitoring and investigating any suspected and confirmed management fraud. Dada, Owolabi, and Okwu (2013) study the relevance of forensic accounting in the effective reduction in fraudulent practices in Nigeria. The results of their hypotheses tested revealed that fraud reduction is significantly and positively related to fraud investigation and detection through forensic accounting.

Sowjanya and Jyotsna (2013) showed some data mining techniques for fraud detection and prevention using fuzzy set theory to support the study and concluded that using only financial statements data may not be sufficient for detections of fraud without the application of data mining. Iztok (2013) examined the perceptions of criminal investigators and state prosecutors with respect to the investigation of corporate fraud and forensic accounting which the study concluded that criminal investigators and state prosecutors do not feel that they possess sufficient accounting knowledge to effectively investigate records during corporate fraud investigation that involves accounting and financial reports. Dada, Enyi, and Owolabi (2013) examined the application of forensic accounting technique for effective investigation of cases of bribery to ensure proper prosecution of those accused of such practices. The study concluded that applying forensic accounting technique is a viable tool in investigating and detecting cases of bribery and it has a positive relationship with bribery prevention but it has not been applied by anti- 
corruption agency. Moreover, Owolabi, Dada, and Olaoye (2013) determined the extent to which employment of forensic accounting technique can ensure effective prevention of corruption with effective investigation and detection of embezzlement in Nigeria.

\subsection{Theoretical Framework of the Study}

There are two prominent theories of fraud (i.e. Fraud Triangle Theory and Fraud Diamond Theory). The theoretical framework that underpinned this study is Fraud Diamond Theory (FDT) based on the following justifications of comparative analysis of the two theories:

\subsection{The Fraud Triangle Theory (FTT)}

Sutherland (1949) was the first to coin the term "white collar crime theory as cited in Ozuomba, Ofor \& Okoye (2016), and he hypothesis white-collar criminals, where he attributed different characteristics and motives of fraudulent corporate workers than typical street criminals. Later on Cressey (1919-1987) a criminologist who was also student of Sutherland builds on the initial works of the forma, where he set forth the Fraud Theory of Triangle. Cressey (1953) his study focuses on embezzlers whom he termed "trust violators". His hypothesis stated that:

'Trusted persons become trust violators when they conceive of themselves as having a financial problem which is nonshareable, are aware this problem can be secretly resolved by violation of the position of financial trust, and are able to apply their own conduct in that situation verbalizations which enable them to adjust their conceptions of themselves as trusted persons with their conceptions of themselves as users of the entrusted funds or property' (Cressey, I973 cited by Coenen, 2005 and Adebisi, \& Gbeqi, (2015).

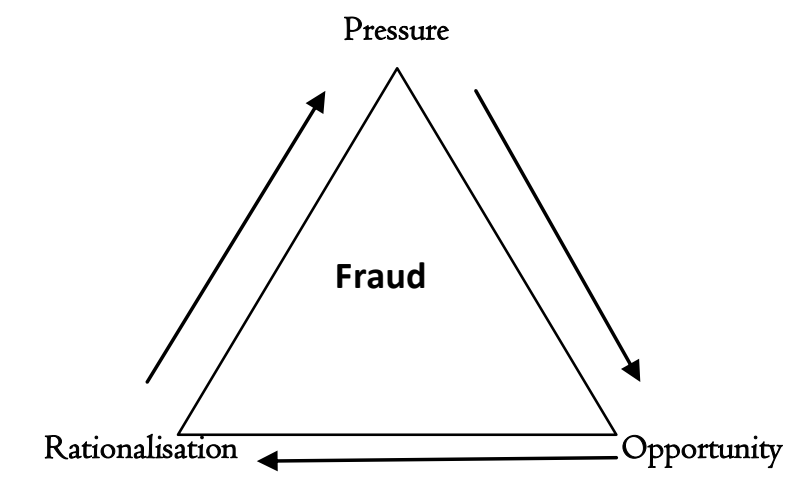

Figure I: Fraud Triangle Theory (FTT)

Source: Coenen (2005) and Adebisi, \& Gbegi, (2015)

Fraud Triangle Theory (FTT) has three postulated assumptions:

- Pressure: - the individual has a need which could not be shared with persons who from a more objective point of view, probably could have aided in the solution of the problem. It can be personal; employment or external pressure, or it can be financial or non-financial pressure.

- Opportunity: - An opportunity affords itself for the individual to solve his financial problem by violating the position of financial trust he holds in his organization. The opportunity could be in the form of inefficient control and supervision in the organization.

- Rationalization: - he makes attempts at self-justification to rationalize and explain his actions and silence his conscience.

Moreover, there are so many criticisms levelled against fraud triangle theory (FTT), among the prominent ones are: Albrecht (2009) criticizes the fraud triangle theory as being limited because it took into cognisance only one dimensional psychological analysis of the initial perpetrator of the fraud. In addition to that, Donegan and Ganon (2008) criticize the theory because it has no any actual empirical support and it also failed to consider other factors that may contribute perpetrators in committing fraudulent act in other words, the theory neglects other factors that contribute to fraud act. Moreover, Cieslewicz (2012) criticizes the theory because it does not explain cultural influences. In a study by Trompeter, Carpenter, Desai, Jones and Riley (2013), criticize fraud triangle theory by taken into cognisant and assuming a single individual acts alone while ignoring group dynamisms. 
In a nut shell, this study criticise this theory based on the following reasons that the theory failed to addressed: It does not take into cognisant, religion differences, cultural differences, Group perpetrators with different ideological act of committing the crime (i.e. Clash of interest of perpetrators).

\subsection{Fraud Diamond Theory (FDT)}

Wolf and Hermanson (2004) proposed a new advanced fraud theory called Fraud Diamond Theory (FDT), which is a replacer of fraud triangle theory (FTT). They argue that the FDT offers a better view of the factors leading to fraud. They added the fourth variable, capacity in addition to three factors theory of Cressey.

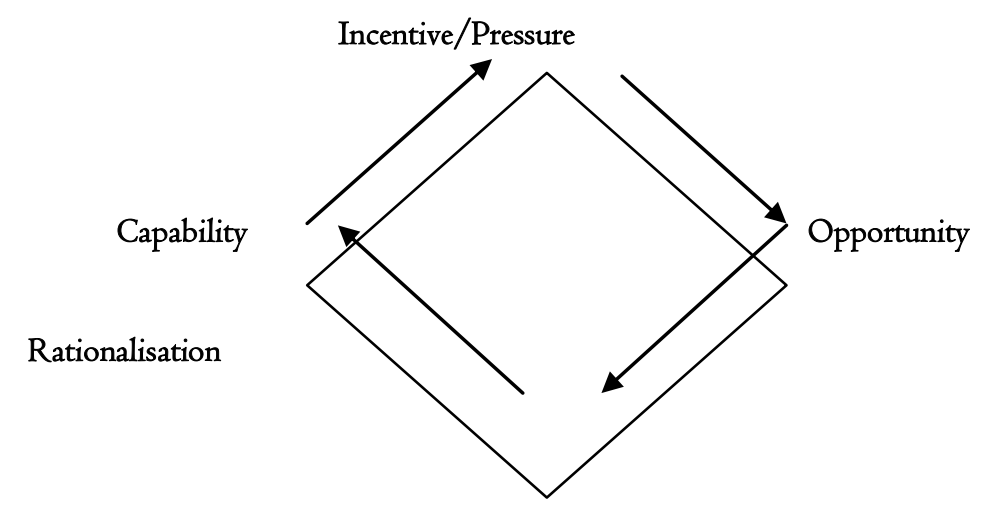

Figure 2: The Fraud Diamond Theory (FDT) Source: Wolf and Hermanson (2004)

Capability means, the fraud perpetrator must have the necessary traits, abilities, or positional authority to pull off his crime act. Fraud Diamond Theory (FDT) offers a better view of the factors to fraud. They are of the believed that many frauds would not have occurred without the right person with the right capabilities implementing the details of the fraud. He must have the capacity to understand and exploit accounting systems and internal control weakness.

For the purpose of this study, the theoretical framework that is underpinning this study is fraud diamond theory, because, Fraud diamond theory (FDT) is complete in exploring the hiding characteristic of fraudster. Moreover, Fraud Diamond theory was premised on the fraud triangle theory with one additional variable which Fraud Triangle Theory (FTT) failed to address (i.e. Capacity) which enable the theory of fraud diamond to have four angles instead of three.

\subsection{Techniques of Fraud Prevention}

Research has clearly shown that the typical organization loses about or getting to about $5 \%$ of its annual revenue each year due to employee fraud in an organization as rightly cited by Reed (2014). It is therefore, pertinent to initiate some techniques that need to be applied so as to curtail and detect the level of it occurrence within an organization. It's also, becomes necessary for every organization to have a master plan of preventing fraud than allowing fraud to be committed and later on to put strong mechanisms of detecting it. In real sense preventing fraud is much easier than recovering losses from the committed fraud. These are the recommended techniques of fraud prevention based on the perception of Reed (2014)

\section{- Know Your Employees}

The researcher looked at it that Fraud perpetrators often display behavioral traits that can indicate the intention to commit fraud since from inception. Observing and given a listening ear to employees can help you identify potential fraud risk. It is therefore, crucial for management to be interacting with their employees and take time to get to know them more and more and listening to employees may also reveal other hidden agendas. For example, as a way of taken revenge an employee may decides to commit fraud because of lack of appreciation and incentive from the business owner. The researcher further reiterated that this may not only minimize a loss from fraud, but can make the organization a better and more efficient place with happier employees.

\section{- Make Employees Aware and Set up Reporting System}

It is the responsibility of the management to ensure that every of their employee within the organization is aware of the fraud risk policy including the classifications of fraud and the consequences associated with committing such an offense. It will also send a signal to those that are planning to commit fraud that management is watching them. Honest employees who are not tempted to commit fraud will also be made aware of possible signs of fraud or theft in an organisation. While most tips come 
from employees of the organization, other important sources of tips come from vendors, customers, competitors and acquaintances of the fraudster. Since many employees are hesitant to report incidents to their employers, consider setting up an anonymous reporting system.

\section{- Implement Internal Controls}

Internal controls are mechanisms, plans and programs implemented to safeguard company's assets, ensure the integrity of its accounting records, and deter and detect fraud and theft in an organisation. Segregation of duties to employees is an important component of internal control that can reduce the risk of fraud from occurring in an organisation. For example, a wholesaler store has one cash register employee, one salesperson, and one manager. The register receipts of cash and check should be tallied by one employee while another prepares the deposit slip and the third brings the deposit to the bank. This can help reveal any discrepancies in the collections process.

Since, internal control system is a continue process, it should be monitored and revised on a consistent basis to ensure they are effective and up to date with technological and other advances. Even, if the management do not have an internal control process or fraud prevention program in place, then they should hire a professional with experience in this area. An expert will analyze the company's policies and procedures then recommend appropriate programs and assist with implementation of such recommended policies and procedures.

\section{- Monitor Vacation Balances}

The management might be impressed by those employees who have not missed a single day of work in many years. While these may sound and be considered as loyal employees, it could also be signed that these employees have something to hide and are worried that someone will detect their fraudulent act if they were out of the office for some time being. It is therefore good idea to rotate employees to various jobs within the same company. This may also reveal fraudulent activity as it allows a second employee to review the activities of the forma.

\section{- Hire Experts}

It should be noted that professional bodies can be winded up such as Certified Fraud Examiners (CFE), Certified Public Accountants (CPA) and CPAs who are Certified in Financial Forensics (CFF) can help you in establishing antifraud policies and procedures. These professionals can provide a wide range of services from complete internal control audits and forensic analysis to general and basic consultations.

\section{- Live the Corporate Culture}

A favourable conducive environment or positive work environment can prevent employee from committing fraud and theft. There should be a clear organizational structure, written policies and procedures and fair employment practices. An open-door policy can also provide a great fraud prevention system as it gives employees open lines of communication with management. Business owners and senior management should lead by example and hold every employee accountable for their actions, regardless of position.

\section{Methodology}

The study is based on content analysis. By means of reviewing the findings of other researchers, thereby taken a stand based on the justifications given by the previous studies. Moreover, the study is descriptive research in nature. Since descriptive research specifies the nature of a given phenomenon.

\section{Discussions}

The research questions were formulated. Does a forensic accounting technique really prevent fraud in Nigeria Public Sector? How does a forensic accounting technique prevent fraud in Nigeria Public Sector? These are some of the findings from the study:

Research has clearly shown that the typical organization loses about or getting to about $5 \%$ of its annual revenue each year due to employee fraud in an organization as rightly cited by Reed (20I4). It is therefore, pertinent to initiate some techniques that need to be applied so as to curtail and detect the level of it occurrence within an organization. It is also, therefore becomes necessary for every organization to have a master plan of preventing fraud than allowing fraud to be committed and later on to put strong mechanisms of detecting it. In real sense preventing fraud is much easier than recovering losses from the committed fraud. Therefore, organisations can prevent fraud by applying these key techniques: 


\section{I Know Your Employees}

Observing and given a listening ear to employees can help organization to identify potential fraud risk. It is therefore, crucial for management to be interacting with their employees and take time to get to know them more and more and listening to employees may also reveal other hidden agendas. For example, as a way of taken revenge an employee may decides to commit fraud because of lack of appreciation and incentive from the business owner.

\subsection{Make Employees Aware and Set up Reporting System}

The management should ensure that every of their employee within the organization is aware of the fraud risk policy including the classifications of fraud and the consequences associated with committing such an offense. It will send a signal to those that are planning to commit fraud that management is watching them. Honest employees who are not tempted to commit fraud will also be made aware of possible signs of fraud or theft in an organisation.

\subsection{Implement Internal Controls}

Internal controls are mechanisms, plans and programs implemented to safeguard company's assets, ensure the integrity of its accounting records, and deter and detect fraud and theft in an organisation. Segregation of duties to employees is an important component of internal control that can reduce the risk of fraud from occurring in an organisation. For example, a wholesaler store has one cash register employee, one salesperson, and one manager. Since, internal control system is a continue process, it should be monitored and revised on a consistent basis to ensure they are effective and up to date with technological and other advances.

\subsection{Monitor Vacation Balances}

The management might be impressed by those employees who have not missed a single day of work in many years. While these may sound and be considered as loyal employees, it could also be signed that these employees have something to hide and are worried that someone will detect their fraudulent act if they were out of the office for some time being. It is therefore good idea to rotate employees to various jobs within the same company. This may also reveal fraudulent activity as it allows a second employee to review the activities of the forma.

\subsection{Hire Experts}

It should be noted that professional bodies can be winded up such as Certified Fraud Examiners (CFE), Certified Public Accountants (CPA) and CPAs who are Certified in Financial Forensics (CFF) can help you in establishing antifraud policies and procedures. These professionals can provide a wide range of services from complete internal control audits and forensic analysis to general and basic consultations.

\subsection{Live the Corporate Culture}

A favourable conducive environment or positive work environment can prevent employee from committing fraud and theft. There should be a clear organizational structure, written policies and procedures and fair employment practices. An open-door policy can also provide a great fraud prevention system as it gives employees open lines of communication with management. Business owners and senior management should lead by example and hold every employee accountable for their actions, regardless of position.

The paper discovered that application of forensic accounting techniques are the only remedy of curtailing the issue of fraud more especially in the case of Nigeria and the study also disclosed the consequential side effect of fraud and it detriment. Moreover, many Studies have also equally established positive relationship between forensic accounting and fraud prevention/detection.

It has been observed that Fraud significantly affects the economic growth and development of any nation (i.e. Nigeria). In addition to that, the rate at which prevalence of fraudulent practices occurred in the Nigerian public sector has brought set back to the economy, hardship to the citizens of the country as a whole and lack of integrity and respect before the international leaders of the recognized world.

For empirical study, primary data or secondary data can be used to do the analysis either by using simple percentages or even tables. Then for testing hypothesis, Analysis of Variance (ANOVA) can be used (Ozuomba, Ofor \& Okoye, 20I6, Adebisi, \& Gbegi, 20I5). Likewise, Descriptive statistics can be used to analyse data (Masoyi, Ernest \& Ogere, 20I4).

\section{Recommendations}

The analytical reviews revealed that there is a significant relationship between forensic accounting techniques and fraud detection in the Nigerian public sector. The study is of the opinion to make the following recommendations as follows: 
The application of 'know your employees' may not only minimize a loss from fraud, but can make the organization a better and more efficient place with happier employees. In addition, the management should make employees aware and set up reporting system. This is by creating more awareness about fraud risk policy including the classifications of fraud and the consequences associated with committing such an offense which will invariably send a signal to those that are planning to commit fraud that management is watching them. Honest employees who are not tempted to commit fraud will also be made aware of possible signs of fraud or theft in an organisation.

There should be segregation of duties among the employees because it is an important component of internal control that can reduce the risk of fraud from occurring in an organisation. Since, internal control system is a continue process, it should be monitored and revised on a consistent basis to ensure they are effective and up to date with technological and other advances.

The study is of the opinion that it is good idea to rotate employees to various jobs within the same organisation. This may also reveal fraudulent activity as it allows a second employee to review the activities of the forma. Moreover, the organisation should hire experts or professional bodies that are Certified in Financial Forensics (CFF) can eventually help organisation in establishing antifraud policies and procedures. These professionals can provide a wide range of services from complete internal control audits and forensic analysis to general and basic consultations.

More steps should be taken to ensure fraud prevention with the application of forensic accounting techniques by government agencies that were saddled with the responsibility of overseeing this aspect of forensic accounting and fraud prevention on behalf of the government. Moreover, an effective and thorough legal framework should be developed and be provided for an effective enforcement of what the law say by government agencies that were saddled with such responsibility.

All money recovered from public sector through forensic accounting should be channelled to capital projects so at it will be a basis for justification of the judicious used of recovered funds to the humanity. In addition to that, Nigerians should embrace the issue of integrity, objectivity, fairness and accountability in their daily life activities in both the public and private sectors.

On aggregate, analytical reviewed from the recognized scholars within the field of forensic accounting revealed that forensic accounting has significant influence toward preventing and detecting fraud in Nigerian public sector (Eiya \& Otalor, 2013).

\section{References}

Abdullahi, R. \& Mansor, N. (2015). Fraud Triangle Theory and Fraud Diamond Theory. Understanding the Convergent and Divergent For Future Research. International Journal of Academic Research in Accounting, Finance and Management Sciences , 5, 38-45.

Adebisi, J. F., \& Gbegi, D. O. (2015). Fraud and the Nigerian public sector performance: The need for forensic accounting. International Journal of Business, Humanities and Technology, 5(5), 67-78.

Adebisi, J.F., Matthew, O.B. \& Emmanuel, Y.V. (2016). The Impact of Forensic Accounting in Fraud Detection and Prevention: Evidence from Nigerian Public Sector. International Journal of Business Marketing and Management (IJBMM), I (5), 34-4I.

Agbiboa, D. E. (2012). Between Corruption and Development: The Political Economy of State Robbery in Nigeria. Journal of Business Ethics , $\operatorname{IO8}(3), 325$ - 345.

Akkeren, J. V. \& Tarr, J. (20I4). Regulation, Compliance and the Australian Forensic Accounting Profession. Journal of Forensic \& Investigative Accounting , 6(3), I - 26.

Al Samara, M. F., AL Afeef, J. H., \& Al Ali, O. A. (2017). The Auditors' Perception on the effect of Forensic Accounting to Mitigate Earnings Management in Jordanian Companies. British Journal of Economics, Finance and Management Sciences, I4(2), I6-29.

Baz. R., Samsudin, R. S., Che-Ahmad, A. B. \& opoola. O. M. J. (2016). Capability Component of Fraud and Fraud Prevention in the Saudi Arabian Banking Sector. International Journal of Economics and Financial Issues , 6 (4), 68-7I.

Blessing, I. N. (2015). Empirical Analysis on the Use of Forensic Accounting Techniques In Curbing. International Journal of Economics, Commerce and Management, $3(\mathrm{I})$.

Claire, A. C., \& Jude, I. O. (2016). FORENSIC ACCOUNTING AND FRAUD DETECTION IN NIGERIAN PUBLIC SECTOR. Igbinedion University Joumal of Accounting Vol, 2, I48-I73.

Coenen, T. (2005). Fraud in Government. Wiscons in Law Journal Article Posted by Casafamar Sundip.

Cressey, D. R. (1953). Other People's Money. Montclair, NJ: Patterson Smith.

Crumbley, D. L. (2003). Forensic and Investigative Accounting. . CCH Publishing.

Dandago, K. (1997). Fraud Detection and Control at Local Government Level. Journal of the Association of National Accountant of Nigeria, 7(4).

Eiya, O. \& Otalor, J. I. (2013). Forensic Accounting as a Tool for Fighting Financial Crime in Nigeria. Research Journal of Finance and Accounting , $4(6), 8$. 
Enofe, A. O., Omagbon, P. \& Ehigiator, F. I. (2015). Forensic Audit And Corporate Fraud. International Journal of Economics and Business Management IIARD, I (7), I - IO.

Enofe, A. O., Ekpulu, G. A. \& Ajala, T. O. (20I5). Forensic Accounting And Corporate Crime Mitigation. European Scientific Journal, II (7), I67-I85.

Enofe, A. O., Ochuwa, A. F., Henrietta, I. O., \& Nosareimen, I. (2017). Expert Witness And Financial Fraud Detection In The Public Sector. International Joumal of Advanced Academic Research / Social \& Management Sciences , $3(7), 70-$ 87.

Enofe, A.O., Okpako P.O. \& Atube, E. N. (2013). The Impact of Forensic Accounting on Fraud Detection. European Journal of Business and Management , 5(26), 6I-73.

Fyneface N. A. \& Oseiweh, O. S. (2017). Forensic Accounting and Fraudulent Practices in the Nigerian Public Sector. International Journal of Arts and Humanities (IJAH), 2(I), I7I- I8I.

Gbegi, D., \& Okoye, E. I. (2013). Forensic Accounting : A Tool for Fraud Detection and Prevention in the Public Sector . (A Study of Selected Ministries in Kogi State). International Joumal of Academic Research in Business and Social Sciences, , 3(3), I - I9.

Idris, O. A. (2017). Forensic Accounting and Financial Fraud in Nigeria: Problems and Prospects. Journal of Accounting and Financial Management, $3(\mathrm{I}), 23$ - 33.

Imoniana, J. O., Antunes, M. T. P., \& Formigoni, H. (2013). The forensic accounting and corporate fraud. JISTEM-Journal of Information Systems and Technology Management, IO(I), I I9-I44.

Kasum, A. S. B. (2009). The Relevance of Forensic Accounting to Financial Crimes in Private and Public Sectors of Third World Economies: A Study from Nigeria. Journal of Business Ethics .

Masoyi, Z. P., Dadi, A. Ernest, E.E. \& Ogere, A. O. (20I4). Application of Forensic Auditing in Reduding Fraud Cases in Nigeria Money Deposit Banks. Global Journal of Management and Business Research: D Accounting and Auditing , I4(3), I-9.

Modugu, K. P \& Anyaduba, J. O. (2013). International Journal of Business and Social Science, 4 (7), 9.

Modugu, K. P., \& Anyaduba, J. O. . (2013). Forensic Accounting and Financial Fraud in Nigeria : An Empirical Approach Kennedy Prince. International Journal of Business and Social Science, 4(7), Pp. 28I-289.

Mukoro, D., Yamusa, O. \& Faboyede, S. (2013). the Role of forensic accountants in fraud. Change and Leadership Detection And National security in Nigeria (17), p. 17.

Mukorol, D. O., Ogijo Yamusa, O., \& Faboyede, S. O. (2013). The Role Of Forensic Accounting In Fraud Detection And National Security. Journal of Management Research , 5 (I), 40-47.

Nekede, F. P., \& Oko, F. P. (2013). An Emperical Analysis of Forensic Accounting and Financial Fraud. African Journal of Social Sciences , $3(4)$, I I2-I2I.

Nonye, A. \& Okoli, B. E. (2015). Forensic Accounting As A Veritable Tool For Efficient Management Of State Owned Public Sectors In Ebonyi State: The Accountants Perspective. British Joumal of Education , 3 (8), 55 -62.

Ogundana, O., Okere, W., Ogunleye, O., \& Oladapo, I. (2018). Forensic Accounting and Fraud Prevention and Detection in Nigerian Banking Industry. COJ Reviews \& Research, I (I), I-8.

Okafor, M. C. \& Agbiogwu A. A. (2016). European Journal of Accounting, Auditing and Finance Research , 4(6), 70-80.

Olajide, D. S. (2014). Forensic Accounting Technique: A Means Of Successful Eradication Of Corruption Through Fraud Prevention, Bribery Prevention And Embezzlement Prevention In Nigeria. Kuwait Chapter of Arabian Journal of Business and Management Review, 4 (I), I76 - 186.

Othman, R., Aris, N. A., Mardziyah, A., Zainan, N., \& Amin, N. M. (2015). Fraud detection and prevention methods in the Malaysian public sector: Accountants' and internal auditors' perceptions. Procedia Economics and Finance, 28, 59-67.

Owojori, A.A \& Asaolu, T.O. (2009). The Role of Forensic Accounting in Solving the Vexed Problem of Corporate World. European Journal of Scientific Research, 29(2).

Ozuomba C.N., Ofor T.N. \& Okoye P.V.C. (2016). Forensic Accounting and Fraud in the Public Sector (A Case of Imo State Ministry off Finance. Research Journal of Management Science, I-6.

Popoola, O. M. J., Che-Ahmad, A. \& Samsudin, R. S. (20I4). Joumal of Modern Accounting and Auditing, IO (8), IO.

Popoola, O. M. J., Che-Ahmad, A. \& Samsudin, R. S. (2014). Task Performance Fraud Risk Assessment on Forensic Accountant and Auditor Knowledge and Mindset in Nigerian Public Sector. Accepted for publication in the Risk Governance \& Control: Financial Markets \& Institutions. , 4(3), 84 - 90.

Umara, I., Samsudinb, R. S. B., \& Mohamedb, M. B. (2016). Challenges of the Economic and Financial Crimes Commission and Their Influence on Adoption of Forensic Accounting: A Conceptual Framework.

Reed, S. (20I4, July 5). Six Strategies for Fraud Prevention in Your Business. http://www.cgteam.com/blog/six-strategies-forfraud-prevention-in-your-business. 
Rezaee, Z., Crumbley, D. L., \& Elmore, R. C. (2003). Forensic Accounting Education: A Survey Of Academicians And Practitioners. SSRN.

Suleiman, N., \& Othman, Z. (2016). Forensic Accounting Investigation for fighting public sector corruption in Nigeria: A conceptual paper. In Proceedings of the Qualitative Research Conference (QRC) 2016 (pp. I94-202).

Umar, I., Samsudin, R. S. \& Mohamed, M. (2017). Appraising the effectiveness of Economic and Financial Crimes Commission (EFCC) in tackling public sector corruption in Nigeria. Journal of Advanced Research in Business and Management Studies, 7(2), I-I2.

Umar, I., Samsudinb, R. S., \& Mohamedb, M. (20I5). The types, costs, prevention and detection of occupational fraud: The ACFE perspective..

Umar, I., Samsudin, R. S. \& Mohamed, M. (2016). Adoption Of Forensic Accounting In Fraud Detection Process By AntiCorruption Agency: A Conceptual Framework. International Journal of Management Research \& Review, 6 (2), I39 I 48.

Watoseninyi, A. B. (1996). Survey of Audit Investigation in Nigeria. The case of frauds. The National Accountant, 6(5).

Wolf, D.T \& Hermanson, D.R. (2004). The Fraud Diamond: Considering The Four Elements of Fraud. The CPA Journal December.

\section{Copyrights}

Copyright for this article is retained by the author(s), with first publication rights granted to the journal. This is an open-access article distributed under the terms and conditions of the Creative Commons Attribution license (http://creativecommons.org/licenses/by/4.0/). 